\title{
Do Fetal Isolated Mild Venticulomegaly Make Any Difference in Regional ADC Values at Magnetic Resonans Imaging?
}

\author{
Fetal Izole Ilımlı Ventrikülomegali Manyetik \\ Rezonans Görüntülemede Bölgesel ADC \\ Değerlerinde Farklılık Yaratır mı?
}

\section{ABSTRACT}

Objective: Ventriculomegaly may not only develop secondary to a process, but it may also be in the form of isolated ventriculomegaly with no specific reason. MRI is performed to show the presence of accompanying pathologies. In this study, we measured $A D C$ values in mild ventriculomegaly cases and aimed to investigate the role of $A D C$ value measurements in predicting neurological prognosis in isolated mild ventriculomegaly during MRI.

Methods: In our study, ADC values were measured of 37 patients detected to be present with mild ventriculomegaly and 17 fetuses in the control group who had no additional central nervous system patology. For the measurement, ROI was placed in differtent brain regions (frontal lobe white matter,occipital lobe white matter, basal ganglia, thalamus, cerebellum and pons). The analysis of the data obtained was performed using the SPSS (20th version) program. MannWhitney $U$ test was applied. Statistical significance level was set as $p<0.05$.

Results: There was no statistically significant difference between the isolated mild ventriculomegaly and the control group in terms of the mean maternal age $(p=0.160)$. Also, no statistically significant difference was observed between the mean gestational age in the ventriculomegaly group and the control group $(p=0.890)$. There was also no statistically significant difference between ADC measurements in different brain regions in the isolated mild ventriculomegaly and the control group $(p=0.807)$.

Conclusion: In order to determine the prognosis in isolated mild ventriculomegaly, other quantitative parameters such as ADC measurement, beyond morphological evaluation and diameter measurement should be determined, and also we need more studies comprising more cases in this field.

Keywords: Isolated ventriculomegaly, ADC measurments, fetal brain

öz

Amaç: Ventrikülomegali gelişimsel, destrüktif ya da obstruktif bir sürece sekonder gelişebileceği gibi hiçbir nedenin bulunamadığı izole ventrikülomegali şeklinde de olabilir. Ventrikülomegali tespit edilen olgularda eşlikçi patolojilerin varlığını göstermek amacıyla Manyetik Rezonans Görüntüleme tetkiki yapılır. Bu çalışmada manyetik rezonans görüntülemede $A D C$ değeri ölçümlerinin izole llımlı ventrikülomegali olgularında nörolojik prognozu öngörmedeki rolünü araştırmayı amaçladık.

Yöntem: Çalışmamızda fetal MRG tetkiki bulunan ılımlı ventrikülomegali tespit edilen 37 hastanın ve santral sinir sistemi patolojisi bulunmayan 17 fetusun diffüzyon ağırlıklı görüntülemede iş istasyonunda manuel olarak frontal ve oksipital loblarda beyaz cevherden, bazal ganglionlar, talamus, pons ve cerebellumdan bilateral simetrik olarak Region of Interest yerleştirerek $A D C$ değerleri ölçüldü. Elde edilen verilerin analizi bilgisayarda SPSS (20. versiyon) programında yapıldı. MannWhitney U testi uygulandı. Istatistiksel anlamlılık düzeyi $p<0.05$ alındı.

Bulgular: izole ılımlı ventrikülomegali grubu ve kontrol grubunda maternal yaş ortalaması arasında istatistiksel olarak anlamlı fark saptanmadı $(p=0.160)$. Ventrikülomegali grubu ve kontrol grubunda gestasyonel yaş ortalaması arasında istatistiksel olarak anlamlı fark saptanmadı $(p=0.890)$. izole ılımlı ventrikülomegali grubu ve kontrol grubunda frontal, oksipital, bazal gangliyon, talamus, pons ve serebellumda $A D C$ ölçümleri arasında istatistiksel olarak anlamlı fark saptanmadı $(p=0.807)$.

Sonuç: İzole ılımlı ventrikülomegalide prognozu belirlemek amacıyla morfolojik değerlendirme ve çap ölçümünün ötesinde, ADC ölçümü gibi mikrostriktüel değişiklikleri yansıtabilecek başka kantitatif parametreler belirlenmesi gerekmekte olup bu alanda daha fazla sayıda olgu içeren daha çok çalışmaya ihtiyaç vardır.

Anahtar kelimeler: İole ventrikülomegali, ADC ölçümleri, fetal beyin
Received: 21.07 .2020

Accepted: 16.09 .2020

Published Online: 30.04 .2021

Cite as: Ayvat Öcal Z, Öztekin Ö, Öztekin D. Do fetal isolated mild venticulomegaly make any difference in regional $A D C$ values at magnetic resonans imaging? İzmir Dr. Behçet Uz Çocuk Hast. Dergisi. 2021;11(1):29-36.

Zeynep Ayvat Öcal

Bakırçay Üniveristesi

Çiğli Eğitim ve Araştırma Hastanesi Radyoloji Anabilim Dalı İzmir, Türkiye

zeynepocal32@hotmail.com ORCID: 0000-0001-9150-7373

Ö. Öztekin 0000-0002-0092-5260 Bakırçay Üniversitesi Çiğli Eğitim ve Araştırma Hastanesi, Radyoloji Anabilim Dalı, izmir, Türkiye

D. Öztekin 0000-0002-4213-7254 Bakırçay Üniversitesi Çiğli Eğitim ve Araştırma Hastanesi, Kadın Doğum ve Hastalıkları Anabilim Dalı, izmir, Türkiye 


\section{INTRODUCTION}

Ventriculomegaly (VM) is defined as the diameter of the atrium of the lateral ventricles just above the thalamus over $10 \mathrm{~mm}$ in the measurements performed in axial plane on the posterior end of the choroid plexus. Atrium diameters in the normal population range between $5.4 \mathrm{~mm}-7.6 \mathrm{~mm}$ on average ${ }^{(1)}$.

Ventriculomegaly is observed regardless of the gestational week in the event that the ventricle diameter exceeds $10 \mathrm{~mm}$ at atrium level. While a ventricular diameter measuring in a range of 10-15 $\mathrm{mm}$ is defined as mild, and severe ventriculomegaly when measured above $15 \mathrm{~mm}$.

It is called asymmetric ventriculomegaly if the difference between the two ventricles is found as > $2 \mathrm{~mm}$ in the measurements performed at the atrium level of the lateral ventricles, and if found lower than this, it is called symmetric ventriculomegaly ${ }^{(2,3)}$.

Mild ventriculomegaly is divided into two subgroups as combined and isolated forms. While there are various neurological diseases accompanying ventriculomegaly in its combined form, there is no etiological cause accompanying ventriculomegaly in its isolated form ${ }^{(4,5)}$. The question of how and how often this pathology should be followed-up is hard to be clarified for perinatologists in isolated mild ventriculomegaly cases. Growth retardation was found in $0-36 \%$ of the cases diagnosed with isolated ventriculomegaly by ultrasonography ${ }^{(6-9)}$.

In studies conducted to determine the prognosis in cases with ventriculomegaly, the underlying cause mostly remains unknown, making it difficult to provide information about the course of the disease and problems arise in patient management. Fetal cranial Magnetic Resonance Imaging (MRI), which also includes ADC sequences, is performed to detect the presence of accompanying pathologies in isolated mild VM cases. In cases such as hydrocephalus and ischemic lesions, interpretation can be made about the prognosis of the disease by making use of the variability in $A D C$ values in cranial MRI. With the same principle, we aimed to provide quantitative data to the clinicians in predicting prognosis by performing ADC measurements in different parts of the brain in fetal MRI examination in isolated mild VM cases.

\section{MATERIAL and METHOD}

In this study, 58 pregnant women with a gestational weeks of 17 to 39 , who were sonographically detected to be present with ventriculomegaly between the dates of January 2014 and January 2016, and who underwent fetal Magnetic Resonance Imaging (MRI) examination were enrolled, while 17 fetuses referred for different reasons between the same dates with no Central Nervous System (CNS) pathology were enrolled in our control group. Diffusion examination was not performed on MRI imaging in 8 of 58 ventriculomegaly cases, and again the ventricle width of 8 of them was measured over $15 \mathrm{~mm}$ (severe ventriculomegaly). ADC measurements could not be performed in 5 of them due to non-diagnostic images related to patient motion artifact. A total of 21 patients were not included in our study group. In our study, while 37 patients were included in mild VM group, 17 patients detected to have no pathology in the CNS were included as a control group. In our study, lateral ventricle diameters of 37 patients with isolated mild VM and 17 patients in the control group were measured. Measurements were carried out just above the thalamus at the level of the atrium in the axial plane, from the posterior end of the choroid plexus and from the middle part of the ventricle height in the coronal plane in an axis perpendicular to the 3rd ventricle (Figure 1). Patients with a diagnosis of mild ventriculomegaly were examined in three subgroups as asymmetric (both ventricle width difference being $\geq 2-2.4 \mathrm{~mm}$ ), symmetric (both ventricle width difference being $<2-2.4 \mathrm{~mm}$ ) and unilateral asymmetric (one-sided ventricular width is normal) ventriclomegaly.

The gestational ages of our cases at the time when they were diagnosed with ventriculomegaly were determined through Ultrasonography (USG) criteria (gestational sac diameter, crown-rump length, biparietal diameter, femur length) and last 

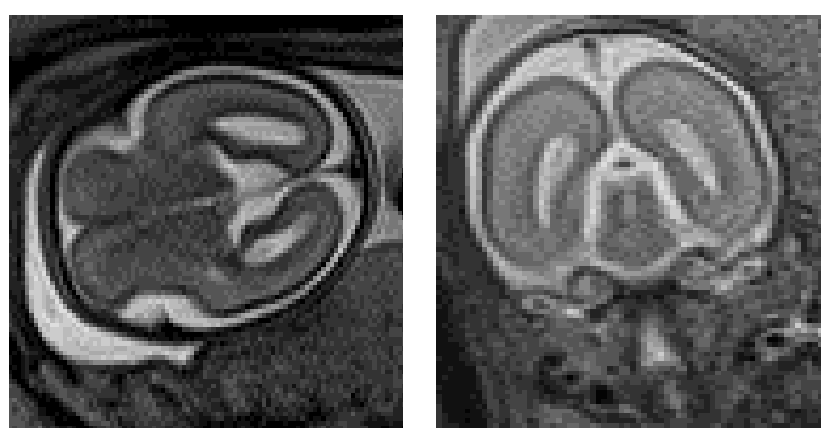

Figure 1. Measurement of ventricle diameter in axial and coronal planes.

menstrual period. Fetal MRI examinations were retrospectively evaluated in our study. MR imaging was performed using a body coil on a $1.5 \mathrm{~T} \mathrm{MR}$ device (Siemens magnetom aera).

Fetus was monitored applying $\mathrm{T} 2$ weighted SingleShot Fast Spin Echo (SSFSE) sequence, with slice thickness of $3 \mathrm{~mm}$, with no gap, Field of View (FOV): 385, matrix: $256 \times 256$, Echo Time (TE): $200 \mathrm{ms,}$ Repetition Time (TR ): 5000 ms, and Fourier Acquired Single-shot Turbo Spin-Echo (FASTE) sequence slice thickness: $3 \mathrm{~mm}$, no gap, FOV: 375 , matrix: $256 \times$ 512, TE: 100 ms, TR: 1298 ms, in sagittal, coronal and axial planes. MR images obtained for ADC measurements were analyzed in DICOM format on the workstation. Manual ADC measurements were made from axial, sagittal or coronal sections by selecting the most immobile section containing the whole brain. For the measurement, The Region of Interest (ROI) was placed symmetrically and bilaterally on the frontal lobe white matter, occipital lobe white matter, basal ganglia, thalamus and cerebellum, and when it comes to the pons level, it was placed on a single area in the center (Figure 2). During the placement of the ROI, the ROI volume was tried to be kept small during the measurements, taking into account the partial volume artifacts, especially in areas containing different tissue components. Although the shape and size of the ROI varied depending on the brain area measured, it was in the range of 32-69 $\mathrm{mm}^{2}$.

The analysis of the obtained data was performed with the SPSS program. The MannWhitney $U$ test, a

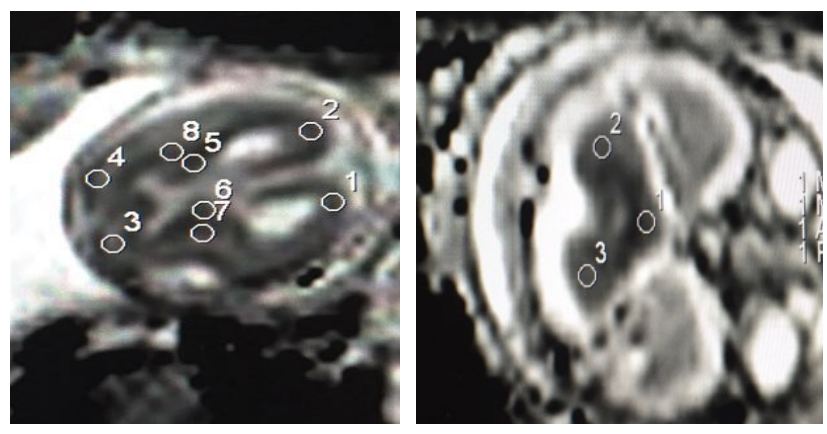

Figure 2. Example of ROI placement during ADC measurement from different parts of the brain (1-2 frontal white matter on the left, 5-6 thalamus, 7-8 basal ganglia, 3-4 occipital white matter), (1 pons on the right, 2-3 cerebellum).

nonparemetric evaluation based on statistical probability, was used. Statistical significance level was set as $p<0.05$.

\section{RESULTS}

Ventriculomegaly was encountered on MRI in 58 patients included in our study. Diffusion examination was not carried out on MRI imaging in 8 of 58 ventriculomegaly cases, while the ventricle width of 8 of them was measured over $15 \mathrm{~mm}$. ADC measurements could not be performed in 5 of them due to non-diagnostic images caused by patient motion artifact. A total of 21 patients were not included in our study group, while the remaining 37 were evaluated as isolated mild ventriculomegaly. 17 fetuses without any CNS pathology were included in our control group.

Mean lateral ventricle diameter measured on MRI was found to be $10.24 \mathrm{~mm}$ in the isolated mild ventriculomegaly group, while the same was 6.40 $\mathrm{mm}$ in the control group. Also, the mean right lateral ventricle diameter of isolated mild ventriculomegaly cases measured on MRI was $10.54 \mathrm{~mm}$, while the mean left lateral ventricle diameter was measured to be $9.94 \mathrm{~mm}$. Of the isolated mild ventriculomegaly cases, 13 were seen to be present with symmetrical bilateral ventriculomegaly and 24 with unilateral asymmetric ventriculomegaly.

While the maternal age distribution of the cases was calculated between 18-44 years, the mean maternal age of 37 cases with isolated mild 
ventriculomegaly was 28.62 SD $( \pm 5.60)$ and the mean maternal age of 17 cases in the control group was 31.05 SD ( \pm 6.12). No statistically significant difference was found between the mean maternal age in the isolated mild ventriculomegaly group and the control group. $(p=0.160)$ (Table 1$)$.

The gestational age distribution of the cases was between 17th and 37th weeks, and the mean gestational age of 37 cases with isolated mild ventriculomegaly was found to be 25.64 SD ( \pm 5.74$)$, while the mean gestational age of 17 cases in the control group was found to be 25.21 SD $( \pm 4.97)$ (Graphic 1). No statistically significant difference was detected between the mean gestational age in the isolated mild ventriculomegaly group and the control $(p=0.890)$ (Table 1).

The mean frontal ADC measurement for 37 cases with isolated mild ventriculomegaly were found to be 1.60 SD $( \pm 0.24)$, while the same measurement performed for 17 cases in the control group was 1.61 SD ( \pm 0.18$)$ (Graphic 2). No statistically significant difference was found between the frontal ADC measurement in the isolated mild ventriculomegaly group and the control $(p=0.807)$ (Table 2$)$.

Table 1. Demographic characteristics.

\begin{tabular}{lccc}
\hline & $\begin{array}{c}\text { Ventriculomegaly } \\
(+) \mathbf{n = 3 7}\end{array}$ & $\begin{array}{c}\text { Ventriculomegaly } \\
(-) \mathbf{n}=\mathbf{1 7}\end{array}$ & $\mathbf{P}$ \\
\hline Maternal age & $28.62 \mathrm{SD}( \pm 5.60)$ & $31.05 \mathrm{SD}( \pm 6.12)$ & 0.160 \\
& & & \\
$\begin{array}{l}\text { Gestational age } \\
\text { (weeks) }\end{array}$ & $25.64 \mathrm{SD}( \pm 5.74)$ & $25.21 \mathrm{SD}( \pm 4.97)$ & 0.890 \\
\hline
\end{tabular}

The mean occipital ADC measurement value of 37 cases with isolated mild ventriculomegaly was detected to be $1.63 \mathrm{SD}( \pm 0.27)$, while the mean occipital ADC measurement value of 17 cases in the control group was 1.68 SD $( \pm 0.21)$ (Graphic 2). No statistically significant difference was found between occipital ADC measurements in the isolated mild ventriculomegaly group and the control group $(p=$ 0.649) (Table 2).

The mean basal ganglia ADC measurement value of 37 cases detected to be present with isolated mild ventriculomegaly was $1.40 \mathrm{SD}( \pm 0.24)$, and the mean basal ganglia ADC measurements of 17 cases in the control group was 1.34 SD $( \pm 0.18)$ (Graphic 2$)$. No statistically significant difference was found between basal ganglia ADC measurements in the isolated mild ventriculomegaly group and the control group $(p=$ 0.408) (Table 2).

Table 2. Comparison of $A D C$ values in patients with isolated mild ventriculomegaly and control group (ADC $\left.\left(\times 10^{-9} \mathrm{~mm}^{2} / \mathrm{sec}\right)\right)$.

\begin{tabular}{lccc}
\hline $\begin{array}{l}\text { ADC Value } \\
\text { measurement }\end{array}$ & $\begin{array}{c}\text { Ventriculomegaly } \\
(+) \mathbf{n}=\mathbf{3 7}\end{array}$ & $\begin{array}{c}\text { Ventriculomegaly } \\
(-) \mathbf{n = 1 7}\end{array}$ & $\mathbf{P}$ \\
\hline $\begin{array}{l}\text { Frontal white } \\
\text { matter }\end{array}$ & $1.60 \mathrm{SD}( \pm 0.24)$ & $1.61 \mathrm{SD}( \pm 0.18)$ & 0.807 \\
$\begin{array}{l}\text { Occipital white } \\
\text { matter }\end{array}$ & $1.63 \mathrm{SD}( \pm 0.27)$ & $1.68 \mathrm{SD}( \pm 0.21)$ & 0.649 \\
$\begin{array}{l}\text { Basal ganglia } \\
\text { Thalamus }\end{array}$ & $1.40 \mathrm{SD}( \pm 0.24)$ & $1.34 \mathrm{SD}( \pm 0.18)$ & 0.408 \\
$\begin{array}{l}\text { Pons } \\
\text { Cerebellum }\end{array}$ & $1.42 \mathrm{SD}( \pm 0.26)$ & $1.34 \mathrm{SD}( \pm 0.19)$ & 0.340 \\
& $1.32 \mathrm{SD}( \pm 0.19)$ & $1.34 \mathrm{SD}( \pm 0.31)$ & 0.498 \\
& $1.55 \mathrm{SD}( \pm 0.22)$ & $1.51 \mathrm{SD}( \pm 0.27)$ & 0.436 \\
\hline
\end{tabular}

The mean thalamus ADC measurement value of 37 cases with isolated mild ventriculomegaly was 1.42 SD $( \pm 0.26)$, while the mean of thalamus ADC measurements of 17 cases in the control group was $1.34 \mathrm{SD}( \pm 0.19)$ (Graphic 2). No statistically significant difference was found between thalamus ADC measurements in the isolated moderate ventriculomegaly group and the control $(p=0.340)$ (Table 2).

On the other hand, the mean pons $A D C$ measurements of 37 cases with isolated mild ventriculomegaly was 1.32 SD $( \pm 0.19)$, while the mean pons $A D C$ measurements of 17 cases in the control group was 1.34 SD ( \pm 0.31 ) (Graphic 2$)$. No statistically significant difference was found between the pons $A D C$ measurements in the isolated mild ventriculomegaly group and the control group $(p=$ 0.498) (Table 2).

Also, the mean cerebellar ADC measurements of 37 cases with isolated mild ventriculomegaly was 1.55 SD ( \pm 0.22$)$, while the mean of cerebellar ADC measurements of 17 cases in the control group was $1.51 \mathrm{SD}( \pm 0.27)$ (Graphic 2 ) and again, no statistically significant difference was found between the cerebral $A D C$ measurements in the isolated mild ventriculomegaly group and the control $(p=0.436)$ (Table 2). 


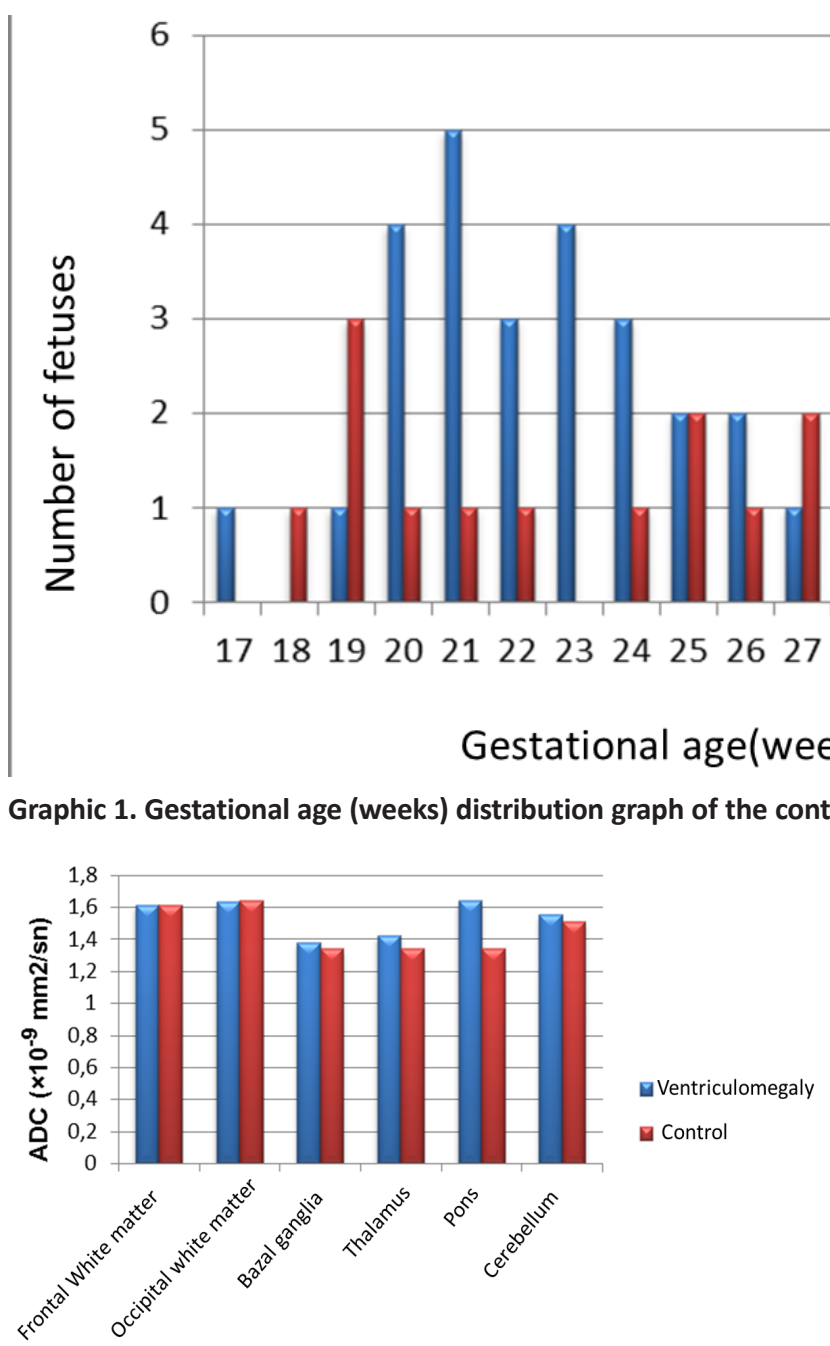

Graphic 2. Mean values of ADC measurements in different regions of the brain in patients with isolated mild ventriculomegaly and in the control group.

In our study, ADC values decreased as the gestational age progressed in occipital white matter, basal ganglia, thalamus, pons and cerebellum, except frontal white matter (Graphic 3).

\section{DISCUSSION}

Different $A D C$ values in different parts of the brain;

In our study, different values were obtained from different parts of the brain in the ADC value measurements performed between 17th and 39th weeks. ADC values in white matter and pons were found to be similar to each other, which were higher than the basal ganglia, thalamus and cerebellum.
Similarly, Chen hoffman et al. ${ }^{(10)}$ found higher ADC values in white matter than in the basal ganglia, thalamus, pons and cerebellum. Gal Yaniv et al. found higher $A D C$ values in white matter in the frontal region than in the basal ganglia, thalamus, pons and cerebellum ${ }^{(11)}$. It has been revealed in previous studies that the reason for the higher ADC values in white matter could be related to the fact that the white matter has not completed its maturation yet, or that the cellularity could be higher in the basal ganglia and thalamus, or that the myelinization is insufficient $(12,13)$. In the studies conducted by Boyer and Vasung, it was revealed that maturation in cerebellum occured earlier than in the occipital and maturation in the occipital was earlier than the frontal white matter, as myelinization progressed from the back to the front, from the bottom up and from the inside out. There was no significant difference in the basal ganglia and thalamus ${ }^{(14,15)}$.

\footnotetext{
ADC values decrease as gestational age progresses;

In our study, as the gestational age increased, $A D C$ values, except for frontal white matter, decreased (Graphic 1). Previous studies showed that ADC values decreased over time towards the end of pregnancy, except for frontal white matter, as gestational age increased ${ }^{(14)}$. In another study, as gestational age
} 

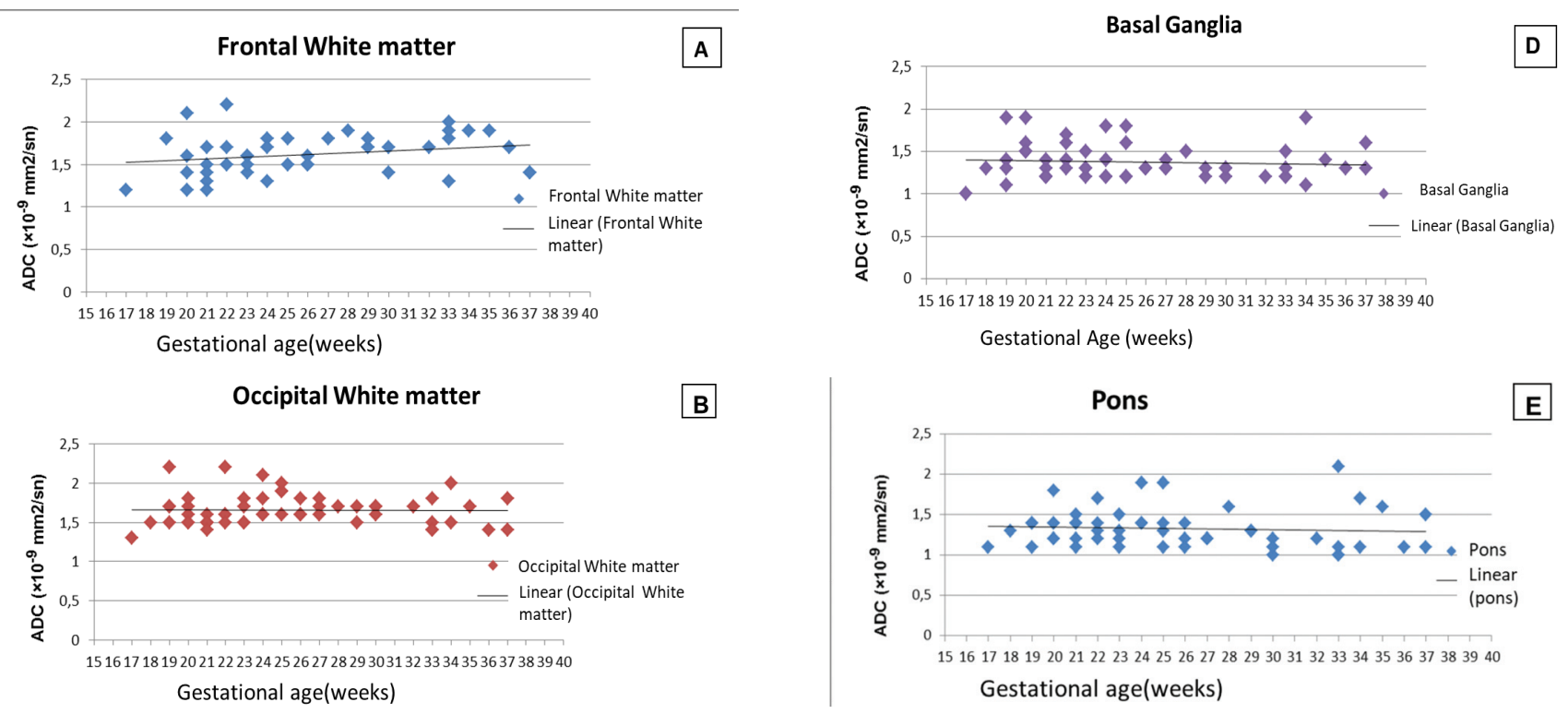

B

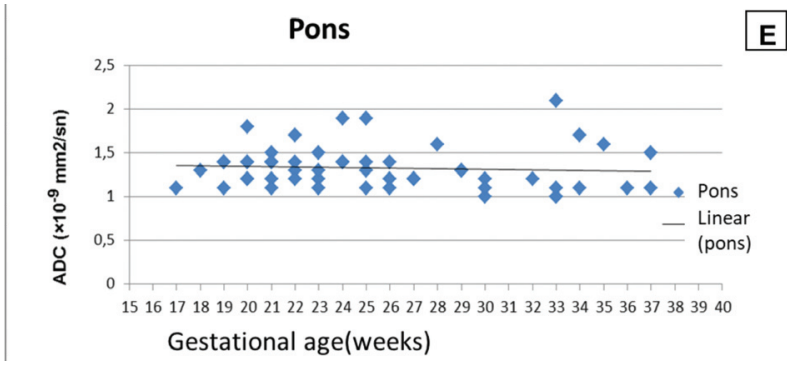

Thalamus
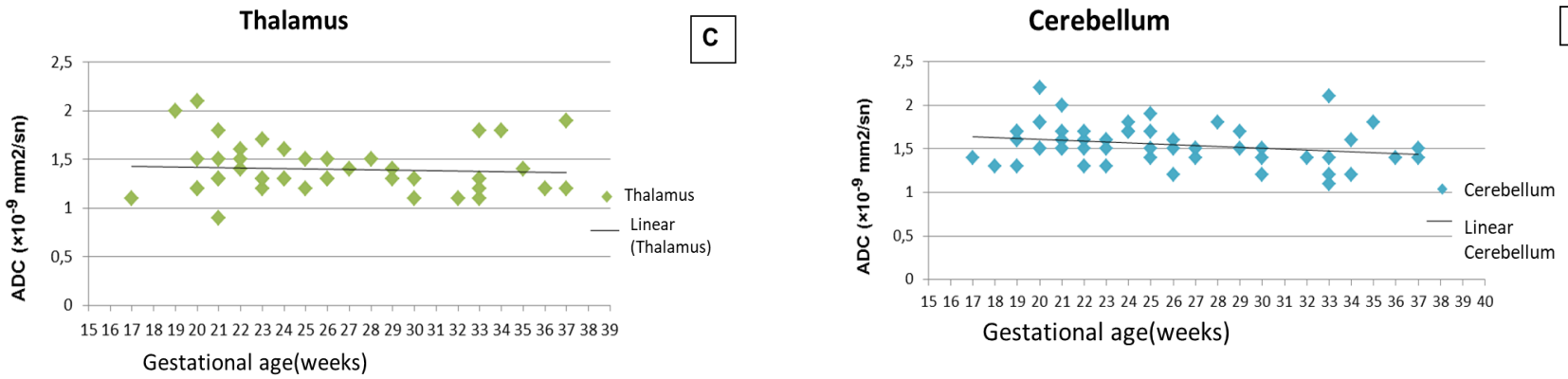

Graphic 3. Scatter plot of ADC values by gestational age in different brain regions (A, B, C, D, E, F). In our study, ADC values decreased in occipital white matter, basal ganglia, thalamus, pons and cerebellum as gestational age progressed.

increased, a decrease in ADC values was only observed in the cerebellum, pons and thalamus, whereas no decrease was observed in other regions ${ }^{(12,13)}$, which was thought to be due to the fact that the gestational age range of the fetuses included in the study was not kept in a wide spectrum. The gestational age range should include all trimesters for significant results. The main reason for the decrease in $A D C$ values as gestational age progresses is that the water molecule content of the fetal brain decreases as the pregnancy progresses, which continues after birth until the age of 2 . At the same time, an increase in the lipid content of the brain is observed with myelination in this process, which contributes to the decrease in ADC values ${ }^{(16,17)}$.

The region with the fastest decrease in ADC values; In our study, the fastest decrease in ADC values as pregnancy progresses was observed in the cerebellum, which was followed by occipital white matter, thalamus, basal ganglia and thalamus, while the minimal increase was observed in ADC values in frontal white matter; this speed was highest in the occipital white matter in a study by Riu Han et al. ${ }^{(18)}$.

While a consensus on patient management and treatment planning has been reached in the combined mild VM and severe VM group there is no consensus on the main topics discussed in the discussion part of the study for patients diagnosed with isolated mild VM ${ }^{(19-21)}$. Although the slight increase in ventricular atrium width is not a prognostic factor in direct relation with fetal neurological development, an answer should be sought for whether the detected VM status is really an isolated one or a component of an additional pathology that cannot be detected in the early period which can be presented late at the 
stage of neurological development.

\section{Limitations}

One of our limitations during the course of the study was that the tissue sampled due to partial volume artefacts could contain structures other than white matter, especially at the level of the frontal lobe, occipital lobe, and basal ganglia while placing the ROI to determine ADC values. Basal ganglia is the first place where the effects of edema caused by increased pressure in the brain parenchyma because of ventriculomegaly due to its location right next to the ventricle. Therefore, the measurements performed may not be precise due to the presence of different tissue compositions in the basal ganglions.

Another limitation of our study is that the number of patients including the control group and subgroups of isolated mild ventriculomegaly was not large enough.

\section{CONCLUSION}

In parallel with the literature, it was revealed in our study that isolated mild ventriculomegaly did not create a significant difference in ADC values in comparison with normal cases in the control group.

More studies with involving more cases are needed to determine quantitative parameters that will be a concrete indicator of prognosis reflecting microstricular changes, beyond morphological evaluation and diameter measurement in isolated mild VM cases.

$\begin{array}{ll}\text { ABBREVIATIONS } \\ \text { VM } & \text { Ventriculomegaly } \\ \text { MRG } & \text { Magnetic Resonance Imaging } \\ \text { CNS } & \text { Central Nervous System } \\ \text { USG } & \text { Ultrasonography } \\ \text { SSFSE } & \text { Single-Shot Fast Spin Echo } \\ \text { FOV } & \text { Field of View } \\ \text { TE } & \text { Echo Time } \\ \text { TR } & \text { Repetition Time } \\ \text { FASTE } & \text { Fourier Acquired Single-Shot Turbo } \\ & \text { Spin-Eko } \\ \text { ROi } & \text { Region Of Interest }\end{array}$

Ethics Committee Approval: Approval was obtained from the Ethics Committee of Izmir Tepecik Training and Research Hospital (19.01.2016 (1/18).

Conflict of Interest: No potential conflict.

Funding: No financial support.

Informed Consent: Informed consent was obtained.

\section{REFERENCES}

1. Ganesh Rao B, BS Ramamurthy. MRI of the Fetal Brain. Indian J Radiol Imaging. 2009 Feb; 19(1): https://doi.org/10.4103/0971-3026.45349

2. Achiron R, Yagel S, Rotstein Z, Inbar O, Mashiach S, Lipitz S Cerebral lateral ventricular asymmetry: is this a normal ultrasonographic finding in the fetal brain? Obstet Gynecol. 1997 Feb;89(2):233-7. https://doi.org/10.1016/S0029-7844(96)00506-6

3. Lipitz S, Yagel S, Malinger G, Meizner I, Zalel Y, Achiron R. Outcome of fetuses with isolated borderline unilateral ventriculomegaly diagnosed at mid-gestation. Ultrasound Obstet Gynecol. 1998;12:23-6. https://doi.org/10.1046/j.1469-0705.1998.12010023.x

4. Kelly EN, Allen VM, Seaward G, Windrim R, Ryan G Mild ventriculomegaly in the fetus, natural history, associated findings and outcome of isolated mild ventriculomegaly: a literature review. Prenat Diagn. 2001 Aug;21(8):697-700. https://doi.org/10.1002/pd.138

5. Saskia J M C Palmen 1, Hilleke E Hulshoff Pol, Chantal Kemner, Hugo G Schnack, Sarah Durston, Bertine E Lahuis "et al. Increased gray- matter volume in medication-naive high-functioning children with autism spectrum disorder. Psychol Med. 2005 Apr;35(4):561-70. https://doi.org/10.1017/S0033291704003496

6. Patel MD, Filly AL, Hersh DR, Goldstein RB. Isolated mild fetal cerebral ventriculomegaly: clinical course and outcome. Radiology 1994 Sep;192(3):759-64. https://doi.org/10.1148/radiology.192.3.7520183

7. Cardoza JD, Goldstein RB, Filly RA. Exclusion of fetal ventriculomegaly with a singlemeasurement: the width of the lateral ventricular atrium. Radiology 1988;169:711-4. https://doi.org/10.1148/radiology.169.3.3055034

8. Mercier A, Eurin D, Mercier PY, Verspyck E, Marpeau L, Marret S. Isolated mild fetal cerebralventriculomegaly: a retrospective analysis of 26 cases. Prenat Diagn. 2001;21:58995. https://doi.org/10.1002/pd.88

9. Bloom SL, Bloom DD, Dellanebbia C, Martin LB, Lucas MJ, Twickler DM. The developmental outcome of children with antenatal mild isolated ventriculomegaly. Obstet Gynecol. 1997;90:93-7. https://doi.org/10.1016/S0029-7844(97)00112-9

10. Wan Yuo Guo, Cheng Yen Chang, Donald MT. Ho, Tai-Tong Wong, Ming Huei Sheu, Huei Cheng Cheng, et al. A comparative MR and pathological study on fetal CNS disorders. Child's Nervous System, 2001;17(9):512-8. https://doi.org/10.1007/s003810100471

11. Gal Yaniv, Chen Hoffmann, Boaz Weisz, Shlomo Lipitz, Eldad Katorza, Debora Kidron, et al. Region selective reductions in brain apparent diffusion coefficient in CMV- infected fetuses Neuroradiology 2014;56:561-7. 
https://doi.org/10.1002/uog.14737

12. Mailath-Pokorny M, Kasprian G, Mitter C, Schopf V, Nemec $U$,Prayer D Magnetic resonance methods in fetal neurology. Semin Fetal Neonatal Med. 2012;17(5):278-84. https://doi.org/10.1016/j.siny.2012.06.002

13. Maas LC, Mukherjee P, Carballido-Gamio J, Veeraraghavan S,Miller SP, Partridge SC, et al. Early laminar organization of the human cerebrum demonstrated with diffusion tensor imaging in extremely premature infants. Neurolmage 2004;22(3):1134-40.

https://doi.org/10.1007/s00247-009-1255-0

14. Boyer AC, Goncalves LF, Lee W, Shetty A, Holman A, Yeo L Magnetic resonance diffusion-weighted imaging: reproducibility of regional apparent diffusion coefficients for the normal fetal brain. 2011 Ultrasound Obstet Gynecol; 38(suppl. 1):56-167. https://doi.org/10.1002/uog.9287

15. Vasung L, Huang $H$, Jovanov-Milosevic N, Pletikos M, Mori S, Kostovic I. Development of axonal pathways in the human fetal frontolimbic brain: histochemical characterization and diffusion tensor imaging. J Anat 2010 Oct;217(4):400-17. https://doi.org/10.1111/j.1469-7580.2010.01260.x

16. Schneider MM, Berman JI, Baumer FM, Glass HC, Jeng $S$, Jeremy RJ, et al. Normative apparent diffusion coefficient values in the developing fetal brain. American Journal of Neuroradiology October 2009;30(9):1799-803.
https://doi.org/10.3174/ajnr.A1661

17. Ramenghi LA, Martinelli A, De Carli A, Brusati V, Mandia L, Fumagalli $M$, et al. Cerebral maturation in IUGR and appropriate for gestational age preterm babies. Reproductive Sciences 2011;18:469-75. https://doi.org/10.1177/1933719110388847

18. Rui Han 1, Lu Huang, Ziyan Sun, Dongyou Zhang, Xinlin Chen, Xiaohong Yang, et al. Apparent Diffusion Coefficient of Normal Fetal Brain Development from Gestational Age Week 24 Up to Term Age: A Preliminary Study Fetal Diagn Ther 2015;37(2):102-7. https://doi.org/10.1159/000363650

19. Sethna F, Tennant PW, Rankin J, Robson SC Prevalence, natural history, and clinical outcome of mild to moderate ventriculomegaly. Obstet Gynecol. 2011;117:867-76. https://doi.org/10.5582/bst.2016.01046

20. McKechnie L, Vasudevan C, Levene M Neonatal outcome of congenital ventriculomegaly. Semin Fetal Neonatal Med. 2012;17:301-7. https://doi.org/10.1016/j.siny.2012.06.001

21. Hannon T, Tennant PW, Rankin J, Robson SC Epidemiology, natural history, progression, and postnatal outcome of severe fetal ventriculomegaly. Obstet Gynecol. 2012120:134553.

https://doi.org/10.5582/bst.2016.01046 